Niniejsza publikacja jest dostępna na licencji Creative Commons. Uznanie autorstwa-Użycie niekomercyjne-Bez utworów zależnych 3.0 Polska. Pewne prawa zastrzė̇one na rzecz autora. Zezwala się na wykorzystanie publikacji zgodnie z licencja - pod warunkiem zachowania niniejszej informacji licencyjnej oraz wskazania autora jako właściciela praw do tekstu. Treść licencji jest dostęna na stronie: http://creativecommons.org/licenses/by-nc-nd/3.0/pl/

Lingwistyka Stosowana 21: 1/2017, 201-202

\title{
Renata CZAPLIKOWSKA/ Artur Dariusz KUBACKI, Methodik des Unter- richts Deutsch als Fremdsprache. Lehr- und Übungsbuch für künftige DaF- Lehrende. Wydawnictwo Biura Tłumaczeń Kubart, Chrzanów, 2016, 240 str.
}

Metodyka nauczania języka niemieckiego jako obcego jest w Polsce od wielu lat obligatoryjnym przedmiotem w planie studiów specjalizacji nauczycielskich na kierunkach neofilologicznych. Do tej pory nie było jednakże opracowania, które w formie zadań podejmuje najważniejsze aspekty nauczania języka niemieckiego na 3. i 4. etapie edukacyjnym. Właśnie tym zagadnieniom poświęcona jest monografia Renaty Czaplikowskiej i Artura Dariusza Kubackiego.

Publikacja ta pod względem kompozycyjnym składa się z przedmowy Autorów, dziesięciu rozdziałów, słowniczka, wykazu literatury oraz załącznika, w którym możemy znaleźć dodatkowe materiały oraz propozycje rozwiązań prezentowanych w książce zadań i ćwiczeń. Ponadto na końcu książki umieszczono wskazówki, dotyczące korzystania towarzyszącego książce kursu online, który jest dostępny na platformie e-learningowej Instytutu Neofilologii Uniwersytetu Pedagogicznego im. Komisji Edukacji Narodowej w Krakowie.

Pierwszy rozdział książki stanowi wprowadzenie do nauczania języka niemieckiego jako obcego i traktuje o poziomach biegłości językowej, zaproponowanych w Europejskim Opisie Kształcenia Językowego. Przedstawia się w nim również główne cele nauczania języka niemieckiego, jak i organizację nauczania tego języka w Polsce. Kolejne dwa rozdziały - drugi i trzeci - poświęcone są rozwojowi sprawności receptywnych i produktywnych. Znajdziemy w nich m.in. podstawowe koncepcje metodyczne rozwoju poszczególnych sprawności językowych oraz służące temu zadania i ćwiczenia. W rozdziale czwartym możemy zapoznać się z założeniami metodycznymi i ćwiczeniami, mającymi na celu rozwój kompetencji gramatycznej, leksykalnej, a także rozwijającymi wymowę i pisownię. Rozdział piąty oraz szósty porusza problemy planowania, organizacji, prowadzenia i ewaluacji zajęć dydaktycznych. Rozdział siódmy opisuje specyfikę nauczania języka obcego na wczesnym etapie edukacyjnym. Jest to wprawdzie rozdział krótki pod względem treści, ale można to wytłumaczyć tym, że recenzowana książka omawia głównie kwestie nauczania języka niemieckiego na 3. i 4. etapie edukacyjnym, co Autorzy podkreślili już w przedmowie. Natomiast ostatnie trzy rozdziały poruszają aspekty dydaktyki języka niemieckiego jako drugiego języka nauczanego po języku angielskim, a także działania mające na celu wspieranie autonomii uczniów oraz kwestie zachowania nauczyciela w procesie dydaktycznym.

Każdy rozdział składa się z zadań. Rola czytelnika nie polega zatem tylko na odbiorze tekstu, ale także na uzupełnieniu go podanymi wcześniej słowami, odpowiadaniu na pytania do tekstu, formułowaniu krótkich odpowiedzi pisemnych do tekstu lub do towarzyszących książce nagrań video. Ponadto dzięki szeregowi pytań, stawianych czytelnikowi zarówno przed prezentacją konkretnych treści, jak też pod 
koniec rozdziału, niejako skłania się czytelnika do refleksji nad przedstawianymi zagadnieniami. Pytania te stanowią także okazję do dyskusji prezentowanego materiału. Taka koncepcja książki świadczy o dużym wyczuciu dydaktycznym Autorów. Natomiast towarzyszący książce kurs online wychodzi naprzeciw nowoczesnym trendom wykorzystywania $w$ procesie dydaktycznym mediów.

Na szczególną uwagę zasługuje umieszczony na końcu monografii słowniczek. Znajdujemy w nim najważniejsze pojęcia z zakresu metodyki nauczania języka niemieckiego, które zostały nie tylko sparafrazowane w języku niemieckim, ale także przetłumaczone na język polski, co stanowi nieodzowną pomoc przy odbiorze podręcznika przez osoby niebędące ekspertami z zakresu metodyki nauczania.

Ponadto czytelnik może zapoznać się z umieszczonymi w załączniku monografii podstawowymi zwrotami i wyrażeniami niemieckiego języka lekcyjnego. W literaturze przedmiotu wielokrotnie podkreśla się fakt, że bez tego typu zwrotów nie można przeprowadzić zajęć w języku obcym (B. Voss 1992: 106 i n.; J. Iluk 1996: 21).

Dzięki szerokiemu zakresowi zagadnień poruszanych w recenzowanej książce można pokusić się o stwierdzenie, że jest to kompendium, zawierające wszystkie podstawowe zagadnienia, niezbędne w dydaktyce języka niemieckiego na 3. i 4. etapie nauczania. Poza tym monografia ta stanowi istotny wkład do tworzenia $\mathrm{w}$ Polsce opracowań dla studentów na temat dydaktyki języka niemieckiego.

Reasumując, można stwierdzić, że monografię Renaty Czaplikowskiej i Artura Dariusza Kubackiego należy ocenić bardzo pozytywnie. Można ją polecić szerokiemu spektrum odbiorców - studentom studiów neofilologicznych, nauczycielom akademickim, nauczycielom gimnazjów i liceów oraz wszystkim tym, którzy chcą doskonalić swój warsztat metodyczny w nauczaniu języka niemieckiego jako obcego. Recenzowana książka jest poniekąd kontynuacją wydanej przez tychże Autorów w 2010 roku książki: Grundlagen der Fremdsprachendidaktik, z którą również warto się zapoznać.

\section{Bibliografia}

Czaplikowska, R./ A.D. Kubacki (2010), Grundlagen der Fremdsprachen-didaktik. Unterrichtsbuch. Kraków.

Iluk, J. (1996), Verstehen und Gebrauch deutscher unterrichtsbezogener Redemittel, (w:) „Deutsch als Fremdsprache“, z. 1, 18-22.

Voss, B. (1992), Sprache im Unterricht - Unterrichtssprache: Zur Bedeutung der Unterrichtssprache im Fremdsprachenunterricht, (w:) U. Jung (red.), Praktische Handreichung für Fremdsprachenlehrer. Frankfurt am Main, 105-112.

Katarzyna SOWA-BACIA

Uniwersytet Pedagogiczny im. Komisji Edukacji Narodowej w Krakowie 